\title{
The Primary School Students of 1950s' Yozgat: Our Memories about Our Primary School Education
}

\author{
Mehmet Saglam \\ Department of Pre-School Education, Faculty of Education, Bozok University, Turkey
}

Copyright (C) 2015 by authors, all rights reserved. Authors agree that this article remains permanently open access under the terms of the Creative Commons Attribution License 4.0 International License

\begin{abstract}
The objective of the study is to lay bare the educational memories of primary school students in 1950s' Yozgat city which is in the center of Turkey. Memories that belong to education are also reflections of the individuals' past educational practices. Why they take part in lives of individuals as memories may let us see the importance of educational practices at schools. The method of the study is oral history which helps us see the hidden educational experiences of primary school students in the form of memories. The people chosen for the research group were reached by the snowball method. 22 interviews were actualized. Two of them were for testing. Unlike the real names of the interviewed people, the narratives of the graduates of the period were presented in their original form. Different narratives which are exclusive due to their originalities take place in the memories of the students of period. There are also memories which cover their experiences out of school as well. Being beaten, enjoyed by their teachers, their educational practices, playing games, looking after their animals or cattle and poverty are some of the practices which appear in their memories. The memories are considerably significant not only for the educational practices at school but also for the history of children and educational institutions.
\end{abstract}

Keywords Oral History, School Experiences, Memories, Education, Yozgat

\section{Introduction}

In general students as the underrepresented part of education posit the basic domain in education however, what they experience as part of their educational experience is commonly ignored while education is taken into consideration by the mainstream educational policy. What they have experienced during their education embodies what take part as educational practices in schools from their point of view and enrich our generic knowledge about education.
To this end, presenting the various memories of primary school students of Yozgat city in 1950s with oral history method which is considered to be particularly appropriate for educational research as educationalists are interested in 'getting at the experience' rather than at facts (2) enable the researchers to be hip to the necessity of these experiences for an entire comprehension of education.

In this sense, the studies actualized by oral history on educational experiences have risen and pursued to produce a broader dialogue in the interdisciplinary studies recently. Sağlam's (14) Primary school students of 1980's Turkey: remembering their teachers brings out the reminiscences of the primary school students 1980's Turkey and helps researchers consider the overall grounds for recall by the students who are not only the observers of educational practices but also have substantial role in the social construction in whole. Moreover, Arat's Where to look for the truth: memory and interpretation in assessing the impact of Turkish women's education concerns about women's assessments of their educational experience and lets their voices be heard and locate the social and cultural determinants of gender relations and their reproduction (2). Additionally, Tan's An Oral Project with the Children of the Republic endorses these studies through enacting the educational and childhood experiences of those who were primary school students just after the foundation of Turkish Republic (18).

Oral history is also seen as a useful tool and frequently employed in teaching social science courses. Redfern's Oral History in Schools: Why Brother explicitly reveals the thumping contributions of oral history in history teaching (12). Besides, Ross' Children becoming historians, an oral history Project in a primary school, describes how children of seven to ten years of age can acquire certain historical skills through oral history work (13). In sum, juxtaposing the myriad studies about education based on educational experiences lets the researchers embrace components of education. Also the crux of the narratives derived from educational experiences is to have them be cognizants of their importance while reconsidering education. 
1950-1960's Period Statistics of Primary School and Population in Turkey

To comprehend atmosphere of 1950s in which they got their primary school education, it can be sensible to present some educational and population statistics of the period. In 1951 only $12 \%$ of the general population was attending to primary school. In 1961, this dropped to $9.6 \%$. It is because despite the increase in population, the enrollment rate did not go up that much. During 1957-1958 educational year 1.038.779 of 3.318.000 population that is expected to attend to primary school was illiterate. 917.524 of them were living in the villages. In 1951, while 1.016 .915 (62.9\%) boys were at primary school, $599.711(37.1 \%)$ girls were at primary school. In 1960-1961 the boys' number rose to 1.800 .026 'ya $(\% 62.8)$ and the Girls' increased in 1.066 .475 (\%37.2) (1, 16). The percentages stayed almost the same despite the increase in the population.

In 1950 the total population of Turkey was 20.947.188, ( $30 \%$ in the cities), ( $70 \%$ in the rural areas). These percentages changed as $31.92 \%$ in the cities and $68.08 \%$ in the rural areas in 1960 (20). These figures are important owing to the fact that there is a close relation between the educational services, opportunities and the density of the population in different regions (8). Yozgat, situated in the center of Turkey, is known as a rural area where apart from the city center, the periphery used to get less educational opportunities and facilities. In 1950 only $32.51 \%$ of 17.856 .865 who were over 6 age were literate $(45.52 \%$ of them were men, $19.45 \%$ of them were women). In 1960 $39.51 \%$ of 22.542 .016 was literate. $(53.63 \%$ of them were men, $24.84 \%$ of them were women) (20).

\section{Methodology}

In this research, the data have been collected from the narratives of 1950-1960 period primary school students of Yozgat city withal oral history methodology as well as personal libraries (photographs etc.), diaries, their educational documents such as, their school registration forms, degrees, transcripts, photographs etc., When accessing to the sentiments of those who lived in past oral history has a considerable posturing and function (7). According to P. Thompson (19) oral history is a history built around people. It thrusts life into history itself and it widens its scope. According to Yow (24) it is the recording of personal testimony delivered in oral form. Oral history methodology allows the voices of those that have been partially or totally ignored, marginalized or silenced within particular contexts to be heard $(6,22)$. It lets ordinary people seek to understand the upheavals and changes they experience in their own lives. In oral history the sense of time is not strictly linear and 'recalling past assessment' is different from 'making present assessment of the past' (4). Thompson believes that oral evidence breaks through the barriers between the chroniclers and their audience; between the educational institution and the outside world. It is peculiarly suited to project work both for groups and for individual student enterprise: in schools, universities, colleges, adult education or community centers (19).

Oral history has been an appealing method utilized in interdisciplinary studies and for most kinds of history some shift of focus recently. It is commonly consulted for the history of institutions, family, education etc., $(21,10)$. Thence, the educational historians become concerned with the experiences of children and students as well as the problems of teachers and administrators (19). What is more, it would benefit those of us in the educational community by providing rich data (9). Above all, it is almost impossible to reach to the teachers' educational practices in the written documents. Thus, attaining to them with the views or words of students who are reciprocally active during the educational process becomes indispensable for the studies on education at large.

\section{Study Group}

The universe of the research group is the 1950s' Yozgat primary school students. Those who were interviewed with were chosen among the people who were primary school students between 1950 and 1960 in Yozgat city. Despite preferring to reach both men and women, it was not possible to reach to the women owing to both their lower attendance to primary school in number and not continuing secondary and high school.

\section{Research Instrument}

The data collected for this study were derived from the semi-structured interviews $(2,5)$ that were carried out with 1950-1960 Yozgat primary school students via a recording device. For this study, totally 22 interviews with twenty one men and a woman were carried out. Two of them were for testing. They were reached via snowball method. An appointment was taken for each person to interview with. Before each interview, he or she was informed about the research and asked if they were suitable for the interview. Then, each of the interviews was recorded by a recording device and then transcribed in its original form. Lastly, text reflecting their diverse memories was reconstituted. The open-ended questions that were expected to be responded by the interviewees were about their demographic information and their memories belonging to their primary school education in general $(14,17)$. Apart from the demographic questions that describe where they had been born, what jobs their parents had been doing, how many brothers and sisters they had etc., the fundamental question was whether they had memories about their primary school education.

\section{Procedure}

For this study, at the first stage, the $1950-1960$ period Yozgat primary school students were reached. After the appointments, they were visited either in their residences or offices. They were reached via snowball method. The 
interviews were semi-structured. Before starting the interviews, they completed an oral history data document that includes their names, jobs, address, phone number, when and where the interview was carried out etc., Then at the beginning of the interview each person began to answer some demographic questions and then followed a conversation style with more open-ended questions. The conversations were not completely "interviewee-guided". At times, a question was posed or repeated in different words, by avoiding having debates and refraining from challenging inconsistencies in their reporting (2). After the interviews, an oral history story which describes how the procedure of the interview was and the interview happened was written for each interview (17).

Analysis of the Data

Descriptive analysis was used so as to analyze the interviews. Thus, what they were able to call up about their memories were put into a context and a relation between their memories and the reasons that led to their recollections were established (3). The narratives were evaluated considering their similarities and differences (23). The narratives which display the similarities and differences were classified accordingly. The description of the organized data was directly quoted to the related place in the text in their original form. Yet, the original names of the narrators were not given in the text. Instead, different names but their first letters were the same of the originals were given. The validity and reliability of interviews were proved both by getting the approval of the interviewees after decoding the interviews and the help of an academician about the framework provided previously in order to use the narratives in the text (14).

\section{Findings}

In this part, data relevant findings reached after the data collection is presented. Except two, twenty of those who were interviewed with as 1950-1960 Period Yozgat primary school students were able to recall their various memories which are being beaten, enjoyed by their teachers, their educational practices, playing games, looking after their animals or cattle and poverty and experiences in general.

\section{Being Beaten}

Being beaten by their teachers or beating a school friend seems to be decisive in the formation of memories in the minds' of primary school students. Melih Korkmaz, Murat Kuralc1, Deniz Soylu, Alpay Recai Kayhan, Ayhan Karsl1, Mehmet Cerit Yaman and Seyhan Okan have memories about their primary school education because of being beaten, beating someone and their fears at school. Murat Kuralc1 whose father was also a teacher at the same school recalls how he was beaten by a teacher in front of other students while he was just at the beginning of his primary school education:
"My best memory is that my father sent me to Mr Sitkl. It was December. I think I must have been poor in reading. My father had sent me to Mr Sitkl as he was the most disciplined teacher. I was just a little child. I was sent with the servant. He knocked the door. There a harsh sound 'enter' I was naturally expecting that my teacher was going to dandle my hair and let me sit. He told me that 'teacher's son I will ask you a question' I was not a successful student. He asked me a math question that I found some meaningless terms (multiply, equal). I could say nothing. He said 'come I will show you how it will be answered.' He took from my ears. I never forget it. He hit my head to the blackboard. He said 'answer it once again.' I said four with fear. He said. 'Ok. Sit down.' My meeting with my second teacher happened like that."

Moreover, Deniz Soylu who used to be a primary school student in a village depicts his memory as: "The most important memory I keep in mind is beating the students. It influenced me a lot. I still know those people and they know me too. The teachers called the students to the board and asked them questions, when they could not answer he called me as well. I was able to do. He had those who couldn't do beaten. It was not a good education style. He got me to beat, slap them. He got them spat. They were the children of the poorest families. Do they have lamp at home? No. Is there a mother at home? No. Is there a good father? Actually, this was teacher's fault. Then these children wanted to beat me in the streets."

Another student of the period, Mehmet Cerit Yaman, finds the school uncomfortable. He remembers that he was so anxious at school that as though he was going to be called and asked something by the teachers. That seems to be the reflection of discipline: "What I recall is that I remember that I was going to school anxiously as we felt being observed. I would be asked something and could not answer back. I always felt surveillance of them. I remember going to school in fear."

\section{Being Enjoyed by the Teachers}

A few students have memories because of the fact that they liked being enjoyed by their teachers. When the students are liked by their teachers, this helps them remember their teachers and have special memories about them. For instance, Miraç Karlı, Deniz Soylu and İsmail Aksaç have memories which reflect their teachers' affections. Deniz Soylu puts it "What I do not forget is my teacher's love for me. I still like that feeling. I cannot forget it." Miraç Karlı's memory also is related with the educational practices and his teachers' love for him. He describes one of his dialogues with his teacher as "There is one thing I never forget. I was class representative at third grade. My teacher had come and talked something with the students. I had not noticed his coming. The children were standing up. Suddenly, I screamed them as 'shut up, sit down'. Then I noticed that the teacher was in. I just stayed there. However, the teacher said nothing to me, smiled at me and did nothing to me. He liked me there. I never forget that." 


\section{Educational Practices}

The students of the period also have memories owing to their educational practices at school. This displays that whatever influential take part at school as educational practices pave the way for their memorization. For example, Ercan Doğan, İsmail Aksaç, Serkan Yenice and Mustafa Aykut İsyancı have memories resulted from the educational practices at school. Serkan Yenice recalls one of his memories as a part of course practices: "At primary school they were teaching us knitting at painting and work course. While I was knitting my friend, the son of head master of the school, was sitting next to me. His shaft sank into my eye and it was not able to be taken from it. I was taken to the hospital. I remember that. It was taken out of my eye at the hospital."

İsmail Aksaç's memory is a great example to delineate teachers' pedagogical aspects during educational process in classroom. It reverberates how their teacher was remunerating her students who were successful and poor. "I was a good student. Her salary was 250 Turkish liras (TL). There was no consumption as we have today at that time. At the end of each month she had 50 TL. What did she do with that money? One day we saw her that she had put a pair shoes on her desk, child shoes. She said that 'children, today we would have a song contest. Whoever had won would get it.' Actually, she knew who was good at singing and needed shoes. Not to take offense of the children, she had us sing and gave it to the one who won the contest. She did not let us feel that she had directly bought that for the one who needed it."

\section{Playing Games}

Playing games have impact on their remembrances as memories. Two of those who were calling up their memories build connection between the games and memories. Fahriye Gök who is the only woman interviewed with and Ayhan İlkcan have reminiscences. Fahriye Gök puts it: "My best memory is that it was snowing much at that time. Our school was out of the village. We all were coming together and going to the hills. We did ski there and played snow ball and trundled along. Our teacher was looking for us. One day we came to school. Everybody was wet. There was a stove. We did burn dung. Do you know dung? He put the dung into the stove and dried us. He told us not to go any more. But we were still going. We did not listen to him as we enjoyed it. That is the most remarkable event that I have never forgotten."

\section{Working out of School: Looking after the Cattle}

The children who were primary school students in the villages recall their memories regarding their workings such as looking after their cattle and working in the fields in the summers or during the school time. Having memories mean being a part of earning their life. This reminds us the necessity of the educational experiences of working children which are parts of their childhood and education (15). Particularly, Hayati Eren and Hasan Başgöz's narratives depict their memories' relation with earning living as children of the period. Hayati Eren puts it "During the school time, were going to school and coming back. During the summer, we helped our parents such as looking after cattle and fields." Hasan Başgöz's memory pictures how hard his childhood was: "We were herding animals from the age of six, seven and eight while we were at primary school. We had sheep, goats. We were at primary school, we had thirty five goats. It was a winter day with my deceased elder brother. There used to be no straw at that time. We were cutting the shoots of trees. The animals were eating them. We were also bringing some of them to home where they could eat as well. One day it was a cold day we collected and enfolded them to home. Our hands were like this, we ran to the round of the stove. My deceased mother said. 'stop my son' she put our hands into cold water otherwise they would have cracked."

\section{Poverty in the Words of Children as their Memories}

Being poor also becomes decisive in the reconstruction of memories as children are exposed to certain expenditures demanded by the teachers and schools. When they are not met by the parents because of their poorness, whatever lived at that time easily appear as the memories of children. İsmail Aksaç and Nuri Keskinoğulları's memories verify how necessary the economic conditions of the families in the reconstruction of childhood memories during their primary education. Nuri Keskinoğulları remembers it as: "My most significant memory is that it was my reclining upon the heater in the post office. I have to tell it. We were given periodicals at that time. The students were given periodicals. I was going to buy it but my deceased dad had not had money. The teacher had told me not to come to the school unless I had bought the periodical the following day. I went home and told my dad and he said 'he did not have money.' I went to the post office next day and reclined on the heater then come back home since he had not given to me the money. When I was asked why I had returned I told them that I felt ill and the teacher sent me home. This happened for two days. The teacher sent a child to my home to find out why I was not going to school. Then it was understood."

\section{General Memories During to Their Primary School Education}

Children of the period also have personal unique memories that may not be classified so as to make any generalization as it is seen in the previous parts. Their exclusiveness comes in sight with their own originalities in connection with the society's approach to having education, business ethics etc., Melih Korkmaz, İsmail Aksaç, Ferhat Zer's memories let us grasp the period perception of a social environment in which they grew up and had their primary school education.

Melih Korkmaz's memory provides remarkable details about the view of social environment to having education. "When I just finished primary school, my father was going to register me to the secondary school in Akdağmaden. That 
night some relatives of us came to our home. I thought that they came to say 'good by' to me. However, they came to my father not to send me to school. My father told them that the teacher had told me to send Melih to school as he was clever. He also wanted me to study as well. They said 'brother if he wants to study, there is the village called Akçaklşla where there is an imam (cleric), take him there. He can read a Fatiha, a Yasin to our deceased people. If you say he is clever, he can study there.' They put pressure on my father until midnight. Despite the fact that he did not want to hurt them, he took me to the school next day for the registration."

Also, İsmail Aksaç' s memory delineates the way the civil servant worked determinedly. He compares today with those days in which he grew up. "My dad was such an honest man. This influenced me a lot. There spread news about corruption. Everybody condemned it. Bribery wasn't something which could be accepted normal as today. My father was a health officer. There was not doctor at that time in small towns. He was responsible. We did not have door bell. There were doorknobs. They knocked the door. 'Mr. Ahmet we have a patient.' At four in the morning my father was getting up. He had a suit, there was no the second. He was wearing it, putting his hat on, having his bag and going to the patient. Then he was coming back. After a while someone else was coming for the same reason and he was doing the same without slogging. My mother was telling him that 'husband husband all you do is out of working hours why do you not take money for that?' My dad was responding as 'the state pays us the salary to take care of people. That is illness. Can you say to people that you should be ill during the working hours?' he did not get money for the services he did overtime."

\section{Discussion and Conclusion}

Disclosing the perdu memories of primary school students of 1950s' Yozgat as one of the real agents of education lets researchers comprehend how essential they are for the history of education, children and the educational practices. These memories lead to the reconsideration of educational practices and education itself as a whole. What comes out as their memories are particularly about being beaten, enjoyed by their teachers, their educational practices, games, both working and going to school and social perspective about education etc.,

Above all, as educational experiences being beaten which is the core of seven memories and is distinctive in the formation of memories. The students who narrate beating as a part of their memories are more in the villages and small towns where beating used to be found just a part of educational practices not only by the teachers but also by the parents (14). The studies about the students' educational experiences including their memories have been prevailing recently; however, they are not directly about their memories. The previously performed academic studies along with this reveal that especially beating and the other memories indicated above have continued throughout time. For educational historians explaining why things happened in the past is not itself enough, they need to explain the continuity as well as the breaks as they necessitate more precision or attention than the change in whole history (11).

The memories of primary school students who had been at primary school at different periods in Turkey have similar contents. Beating, enjoying their teachers, playing games and poverty are also displayed in their memories of those who have been interviewed before by other researchers as well. To begin with, students of early period of Turkish Republic have memories about being beaten. İsmail Karamustafa recalls it as "He had taken from the ears of the child, from the soft part of it and pinched them." Moreover, Lütfi Önay thinks beating was such a practice that had been left during Ottoman education system. "The methods of that period ... beating was the top one. There was a teacher called Pakize. She was beating every day." (17).

Enjoying their teachers easily becomes a part of children's memories. It mostly becomes remarkable in the rural areas since they are found as the only people to learn about outdoor (15). İsmet Varol: "She was our mother. For us, teacher also means mother and father" (17). The students of primary school students' of 1980s' Turkey also tell their memories about their games and how poor they had been while they were at primary school. To illustrate, Füsun Börekçi and Fahriye D. Doğu narrates their games as their memories. Füsun Börekçi: "We were playing line game, skipping rope, dodge ball, volleyball with our male friends."Fahriye D. Doğu recalls it as "We were playing ball, skipping rope with the boys" (15).

One of them Hasan Tatık puts it as "The best memory about school was that I think I was at third grade. It was April the 23th. My father had given me 25 penny. I went to the grocer and bought five sweets with it. I ate two and sold three of them and put little stones instead of the sweets and sold them to my friends with 35 penny to buy biscuits with it. I sold them with 50 penny. In that way I got two liras. I can remember this very well." (15).

In short, students' memories based on educational experiences shaped within the educational environment are able to be evaluated in various perspectives. This study displays that students' memories let the educational researchers rethink the reciprocal interaction between the educational practices and their appearances in the memories. The question is what becomes surfaced in the collective narratives of the students as their memories. In other words, what sort of educational practices are effective in order to appear as memories in the minds of primary school' students. To illustrate, if students are given duties or responsibilities during their education, they easily recall them or narrate them as memories $(17,14,15)$.

Also, the social, economic and educational conditions in which they had their education become influential in the formation of their memories. For instance, while the children in the cities recall more about the games they played, the ceremonies they took part etc, the children who were in the 
small towns and villages reflect their poor life conditions. Such as Fevziye Eroğlu, a primary school student of 1980s and had her primary school education in a city recalls her memory as The most important memories are the ceremonies. Our parents came to watch us they our photos were taken every year." Tahsin Koyuncu who was a primary school student in a village in 1980s' Turkey puts it as "We had a photo taken about school. I just can remember that. There was no money to get a photo taken. I do not know but I was able to save some money for that photo. There was another photo of me but since I could not pay for it, I could not get it" (15).

Furthermore, more is to be done as part of educational studies on children's memories about their education in order to see and explain their historical and educational change and significance both for history, sociology of education and the teachers' education. All in all the teachers' candidates ought to be informed about the memories of the children so that they can be aware of their necessities. Thus, this helps them use more effective teaching methods in their classes in the future.

\section{REFERENCES}

[1] Akyüz, Y. (1985). Türk Eğitim Tarihi (Başlangıçtan 1985'e). Ankara: Ankara Üniversitesi Eğitim Bilimleri Fakültesi Yayınları. No: 149.

[2] Arat F K, Zehra. (2003). Where to Look for the Truth: Memory and Interpretation in Assessing the Impact of Turkish Women's Education. Women's Studies International

[3] Büyüköztürk Şener, Çakmak, Ebru Kılıç, Akgün, Özcan Erkan, Karadeniz Şirin \& Demirel, Funda (2013). Bilimsel araştırma yöntemleri. Ankara: Pegem Akademi Yayınları.Forum, Vol: 26, No, 1: 57-68.

[4] Carsten, Janet (1995). The politics of forgetting: Migration, kinship and memory on the periphery of the south-east Asian State. Journal of the Royal Antropological Institute, 1 (2), 317-335.

[5] Ekiz, Durmuş (2013). Bilimsel Araştırma Yöntemleri. Ankara: Anı Yayıncilik.

[6] Haynes, Kathryn (2006). Other Lives in Accounting: Critical Reflections on Oral history Methodology in Action, University of York, (Available online at: http://eprints.whiterose.ac.uk//2582/1/ymswp21haynes.pdf), Retrieved on June 18, 2013.

[7] Hoşgör, Ayşe Gündüz (2000). Methodological and Ethical Concerns Regarding Application of Oral History Techniques in Sociology. IOHA Conference, Vol: I, İstanbul: 330-335.
[8] Karakütük, K. (1995). Nüfus ve Eğitim. Demokratik Eğitim Kurultay1. 603-644.

[9] McAdoo, Harriette (1980). Oral History as a Primary Reseource in Educational Research. J. Negro Educ. 49 (4) 414-22.

[10] Öztürkmen, Arzu (2001). "Celebrating National Holidays in Turkey: History and Memory." new perspectives on turkey, $25,47-75$.

[11] Prins, Gwyn (1991). Oral history. In Peter Burke (Eds.), New perspective on historical writing (114-139). University Park, PA: The Pennsylvania State University Press.

[12] Redfern, Allan (2000). Oral History in Schools: why Brother? IOHA Conference, Vol: I, İstanbul: 341-345.

[13] Ross, Alistair (1998). Children Becoming Historians: an oral history project in a primary school. In R. Perks \& A. Thomson (Eds.), The Oral History Reader (433-447) London $\&$ New York: Routledge.

[14] Sağlam, Mehmet. (2015). Primary school students of 1980's Turkey: remembering their teachers. Educational Research and Reviews, Vol. 10 (6), pp. 761-768.

[15] Sağlam, M. (2013). The Narratives of 1970s' Primary Schools' Children in Turkey: Childhood and Remembering the Past. Global Advanced Research Journal of History, Political Science and International Relations. Vol: II, 003-013.

[16] Sakaoğlu, N. (2003). Osmalı'dan Günümüze Eğitim Tarihi. İstanbul: İstanbul Üniversitesi Yayınları.

[17] Tan, M., Şahin, Ö., Sever, M., and Bora, A. (2007). Cumhuriyet'te Çocuktular. İstanbul: Boğaziçi Üniversitesi Yayınları.

[18] Tan, Mine G. (2000). An Oral History Project With the Children of the Republic, IOHA Conference, Vol: I, İstanbul: 346-355.

[19] Thompson, Paul (1988). The Voice of the Past: Oral History. Oxford: Oxford University Press.

[20] Türkiye İstatistik Kurumu. Temel İstatistikler. www.tuik.gov.tr/Ust.Menu.do?Metod=temelist. (Retrived on 26, June, 2015).

[21] Vansina, Jan (1985). Oral Tradition as History. Wisconsin: The University of Wisconsin Press.

[22] Wall J (2012). Can Democracy Represent Children? Towards a Politics of Difference, Childhood, http://chd.sagepub.com/ 86-100. (Retrieved on 15January, 2014).

[23] Yıldırım, Ali \& Şimşek, Hasan (2005). Sosyal Bilimlerde Nitel Araştırma Yöntemleri, Ankara: Seçkin.

[24] Yow, Valerie Raleigh (2005). Recording Oral History. N. York, Toronto \& Oxford: Altamira Press. 